\title{
Community structure and decadal changes in macrozoobenthic assemblages in Lake Poyang, the largest freshwater lake in China
}

\author{
Y.J. Cai( ${ }^{(1),(2) \star}$, Y.J. Lu ${ }^{(2)}$, Z.S. Wu(1) , Y.W. Chen ${ }^{(1)}$, L. Zhang ${ }^{(1)}$, Y. Lu ${ }^{(2)}$
}

Received February 19, 2014

Revised May 19, 2014

Accepted June 10, 2014

\section{ABSTRACT}

Key-words: Lake Poyang is the largest freshwater lake in China and contains unique Yangtze River, floodplain lake, and diverse biota within the Yangtze floodplain ecosystem. However, knowledge of its macrozoobenthic assemblages remains inadequate. To macrozoobenthos, characterize the current community structure of these assemblages and community structure, sand mining to portray their decadal changes, quarterly investigations were conducted at 15 sites from February to November 2012. A total of 42 taxa were recorded, and Corbicula fluminea, Limnoperna fortunei, Gammaridae sp., Nephtys polybranchia, Polypedilum scalaenum and Branchiura sowerbyi were found to dominate the community in terms of abundance. The bivalves Corbicula fluminea, Lamprotula rochechouarti, Arconaia lanceolata and Lamprotula caveata dominated the community in biomass due to their large body size. The mean abundance of the total macrozoobenthos varied from 48 to $920 \mathrm{ind} \cdot \mathrm{m}^{-2}$, the mean biomass ranged from 28 to $428 \mathrm{~g} \cdot \mathrm{m}^{-2}$. The substrate type affected strongly the abundance, biomass, and diversity of the macrozoobenthos, with muddy sand substrates showing the highest values. Compared with historical data, remarkable changes were observed in the abundance of macrozoobenthos and the identity of the dominant species. The mean total abundance decreased from 724 ind. $\mathrm{m}^{-2}$ in 1992 to $228 \mathrm{ind} \cdot \mathrm{m}^{-2}$ in 2012 . The dominant species have shifted dramatically. Large unionids were dominant before 1998, whereas pollution-tolerant species (e.g., Branchiura sowerbyi) increased in dominance after 2008. Our findings should have implications for the conservation of the benthic biodiversity of this large Yangtzeconnected lake.

\section{RÉSUMÉ}

La structure des communautés et les changements décennaux dans les assemblages du macrozoobenthos du lac Poyang, le plus grand lac d'eau douce en Chine

Mots-clés : fleuve Yangtze,
Le lac Poyang est le plus grand lac d'eau douce en Chine et contient des biotes uniques et diversifiés de l'écosystème de la plaine inondable du Yangtzé. Cependant, la connaissance de ses assemblages macrozoobenthiques reste insuffisante. Pour caractériser la structure de la communauté actuelle de ces assemblages et présenter leurs changements décennaux, des inventaires

(1) State Key Laboratory of Lake Science and Environment, Nanjing Institute of Geography and Limnology, Chinese Academy of Sciences, Nanjing 210008, P.R. China

(2) State Key Laboratory of Hydrology-Water Resources and Hydraulic Engineering, Nanjing Hydraulic Research Institute, Nanjing 210029, P.R. China

* Corresponding author: caiyj@niglas.ac.cn 
lac des plaines inondables, macrozoobenthos, structure

de la communauté, extraction de sable trimestriels ont été menés dans 15 sites de février à novembre 2012. Un total de 42 taxons ont été enregistrés, et Corbicula fluminea, Limnoperna fortunei, Gammaridae sp., Nephtys polybranchia, Polypedilum scalaenum, et Branchiura sowerbyi ont été trouvés dominant la communauté en termes d'abondance. Les bivalves Corbicula fluminea, Lamprotula rochechouarti, Arconaia lanceolata et Lamprotula caveata dominent la communauté en biomasse en raison de leur grande taille. L'abondance moyenne du total du macrozoobenthos varie de 48 à $920 \mathrm{ind} \cdot \mathrm{m}^{-2}$, la biomasse moyenne varie de 28 à $428 \mathrm{~g} \cdot \mathrm{m}^{-2}$. Le type de substrat affecte fortement l'abondance, la biomasse et la diversité du macrozoobenthos, avec des substrats de sable boueux montrant les valeurs les plus élevées. En comparaison avec les données historiques, des changements remarquables ont été observés dans l'abondance du macrozoobenthos et l'identité des espèces dominantes. L'abondance totale moyenne a diminué de $724 \mathrm{ind} \cdot \mathrm{m}^{-2}$ en 1992 à $228 \mathrm{ind} \cdot \mathrm{m}^{-2}$ en 2012. Les espèces dominantes ont changé de façon spectaculaire. Les grands unionidés étaient dominants avant 1998, alors que les espèces tolérantes à la pollution (par exemple, Branchiura sowerbyi) ont augmenté en importance après 2008. Nos résultats devraient avoir des implications pour la conservation de la biodiversité benthique de ce grand lac connecté au Yangtzé.

\section{INTRODUCTION}

Riverine flood plains are among the Earth's most distinctive landscape features and are characterized by high biodiversity and productivity (Tockner et al., 2002; Ward et al., 2002). However, they are also among the most threatened ecosystems worldwide (Nilsson et al., 2005; Vörösmarty et al., 2010). The biodiversity associated with rivers has been neglected in many areas of the world, such as Asia and Africa (Tockner and Stanford, 2002; Arthington et al., 2010). Several studies have shown that the invertebrate production on floodplains can be orders of magnitude higher than in the associated channel; the floodplain macroinvertebrates function as important intermediaries between basal resources and higher trophic levels, such as fish and birds (Covich et al., 2004). Therefore, an improved understanding of macrozoobenthic assemblages is highly significant for developing efficient conservation and management strategies for floodplains. As is well-known, the distribution of benthic invertebrates in floodplain systems is influenced by abiotic habitat parameters such as water depth, current velocity, substratum stability, and grain size (Thomaz et al., 2007; Davidson et al., 2012; Negishi et al., 2012). Johnson et al. (2004) showed that the variation of macrozoobenthic communities across sites in lakes is best explained by habitat-scale characteristics. Differences among substrates (e.g., sand, silt, and aquatic plants) are considered as the most important factors that determine the density, species composition, and richness of macrozoobenthic assemblages (Tolonen et al., 2001; Weatherhead and James, 2001, Dalu et al., 2012).

In the middle and lower Yangtze River drainage basin, there are approximately 108 freshwater lakes with a surface area $>10 \mathrm{~km}^{2}$ and a total area greater than $14226 \mathrm{~km}^{2}$, representing $51.3 \%$ of the total freshwater lake area $\left(>10 \mathrm{~km}^{2}\right)$ in China (Jiang et al., 2009). Historically, most lakes were freely connected with the main course of the Yangtze River and were affected by seasonal flooding. To maintain conditions suitable for fish farming and to protect cultivated lands along the lakeshores from these floods, sluice gates and embankments were constructed starting in the 1950s-1970s, which eventually isolated most of the lakes from the Yangtze River (Pan et al., 2011). To date, only three large- and medium-sized lakes - Lake Poyang $\left(2933 \mathrm{~km}^{2}\right)$, Lake Dongting $\left(2432 \mathrm{~km}^{2}\right)$, and Lake Shijiu $\left(210 \mathrm{~km}^{2}\right)$ - remain freely connected with the Yangtze mainstream (Pan et al., 2011). Although they are now few in number, these river-connected lakes play important roles in maintaining the unique and diverse biota of the entire Yangtze floodplain ecosystem. Lake Poyang and Lake Dongting have four nature reserves in total belong to The Ramsar List of Wetlands of International Importance.

In this study, we investigated the macrozoobenthic assemblages in Lake Poyang, the largest freshwater lake in China. The lake also has immense economic importance for 
Jiangxi Province, and China's State Council recently approved a Lake Poyang Eco-economic Development Zone that includes 38 counties surrounding the lake and more than 28 million people. The lake is important for flood control, transportation, agriculture, aquaculture, tourism, and recreation. Most importantly, it is a drinking water source for several counties (Finlayson et al., 2010). Lake Poyang provides resources for local economic development, although multiple stressors from human activities and abiotic factors are imposed on the lake's ecosystem. The water quality of Lake Poyang has been reported to be declining in recent years. The decrease in water quality may cause significant changes in the lake's benthic communities. However, our knowledge of the macrozoobenthos in Lake Poyang remains limited. Previous studies have concentrated primarily on species composition, abundance, biomass, diversity and spatial patterns of bivalves (Wu et al., 1994, Liu et al., 2008; Xiong et al., 2011a, 2011b; Zhang et al., 2013) and gastropods (Wu et al., 2008). These studies showed that there are 108 species of Mollusca in Lake Poyang, of which more than $50 \%$ are Chinese endemic species. In contrast, few studies have been conducted on other taxonomic groups (e.g., Annelida and aquatic insects) (Xie et al., 1995, Wang et al., 1999, 2007; Ou Yang et al., 2009; Pan et al., 2011). Furthermore, rare researches have been implemented on the factors regulating the community structure of macrozoobenthos (Pan et al., 2011). The principal objectives of this study were to characterize the community structure and spatiotemporal patterns of macrozoobenthic assemblages in Lake Poyang and to examine the effects of substrate type on the characteristics of the macrozoobenthos. Additionally, we revealed the long-term changes in macrozoobenthic assemblages in this lake by comparing our results with historical studies.

\section{MATERIALS AND METHODS}

\section{> STUDY AREA}

Lake Poyang $\left(28^{\circ} 22^{\prime}-29^{\circ} 45^{\prime} \mathrm{N}\right.$ and $\left.115^{\circ} 47^{\prime}-116^{\circ} 45^{\prime} \mathrm{E}\right)$ is located in northern Jiangxi Province along the southern bank of the Yangtze River (Figure 1). Lake Poyang is the largest freshwater lake in China, with an average water depth of $8.4 \mathrm{~m}$ and a storage capacity of $2.76 \times 10^{10} \mathrm{~m}^{3}$ when the water level at Hukou is $21.71 \mathrm{~m}$ (Feng et al., 2012). Lake Poyang is freely connected to the main course of the Yangtze River, and the mean annual lake-river runoff is $1.436 \times 10^{11} \mathrm{~m}^{3}$, which represents $15 \%$ of the average Yangtze River runoff (Finlayson et al., 2010). The main water sources of Lake Poyang are its five tributaries (Ganjiang, Fuhe, Xiushui, Xinjiang and Raohe) and local precipitation (Figure 1). Lake Poyang is a dynamic wetland system; water levels are high during the summer rainy season and decline during the winter dry season, with differences as great as $13 \mathrm{~m}$ within a year. During the wet season from April to September, the floodplains are inundated and thus form a large lake with an inundation area of $>3000 \mathrm{~km}^{2}$ (Figure 1). During the dry season from October to March, the lake's inundation area can shrink to $<1000 \mathrm{~km}^{2}$ that forms a narrow meandering channel (Figure S1, online material, at the address: http://www.kmae-journal.org) (Feng et al., 2012).

\section{>MACROZOOBENTHOS SAMPLING AND MEASUREMENT OF ENVIRONMENTAL PARAMETERS}

Benthic samples were collected quarterly at 15 sites (Figure 1) from January 2012 to October 2012. These stations are regular monitoring stations of the Lake Poyang Laboratory for Wetland Ecosystem Research (PLWER) within the Chinese Ecosystem Research Network (CERN). Although the surface area of Lake Poyang changes substantially in different seasons, these 15 sampling sites are all covered with water throughout the entire year. On each sampling occasion, macrozoobenthos was collected using a $0.05-\mathrm{m}^{2}$ modified Peterson grab, with two grabs comprised a sample at each site, and were pre-sieved in situ through a $250-\mu \mathrm{m}$ mesh size sieve. In the laboratory, the samples were sorted on a white tray, and animals were 


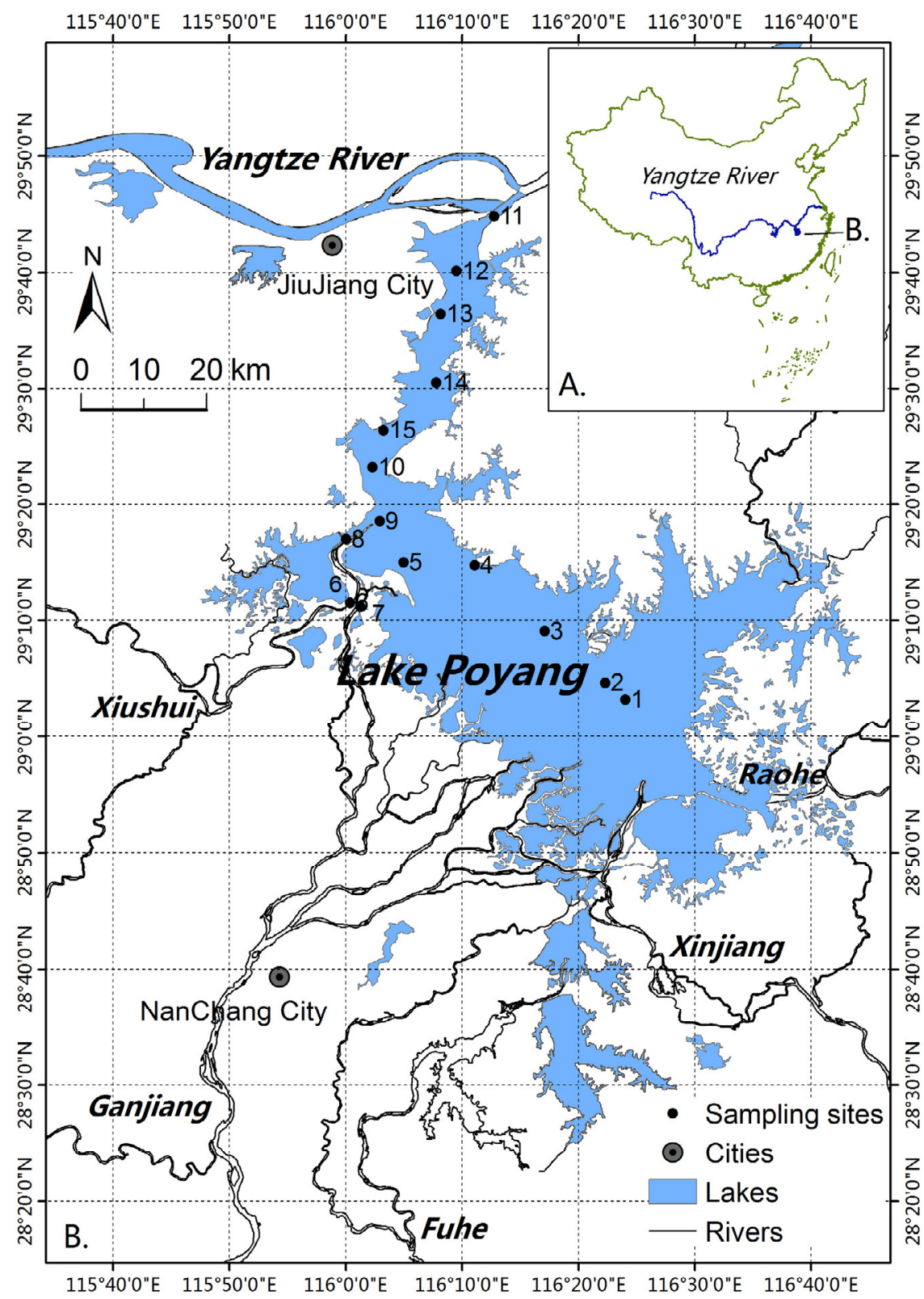

Figure 1

Locations of the sampling sites for macrozoobenthos and environmental parameters in Lake Poyang, China.

preserved in $7 \%$ buffered formalin solution. Specimens were identified to the lowest feasible taxonomic level, counted, blotted dry and weighted to determine their wet weight using an electronic balance (Sartorius BS-124, readability: $0.1 \mathrm{mg}$ ). Molluscs were weighed with their exoskeletons, and the identification and classification of macrozoobenthos were based primarily on Liu et al. (1979), Morse et al. (1994), Wang (2002), and Tang (2006).

The water depth and Secchi depth were measured in the field for all sampling dates. The environmental parameters, including the $\mathrm{pH}$, water temperature, dissolved oxygen, turbidity, and electrical conductivity, were measured using a Hydrolab DataSonde 5 (HydroLab Corporation, Austin, Texas, USA) sensor in situ. Vertically integrated water samples were collected and placed in acid-cleaned 10-L plastic containers which were kept cool and shaded before transportation to the laboratory. The total nitrogen (TN), ammonium $\left(\mathrm{NH}_{4}-\mathrm{N}\right)$, nitrate $\left(\mathrm{NO}_{3}-\mathrm{N}\right)$, total phosphorus (TP), orthophosphate $\left(\mathrm{PO}_{4}-\mathrm{P}\right)$, suspended solids $(\mathrm{SS})$, chemical 
oxygen demand $\left(\mathrm{COD}_{\mathrm{Mn}}\right)$, and chlorophyll a (Chl-a) were measured in the laboratory according to the American Public Health Association (APHA) standards (2012).

\section{> DATA ANALYSIS}

A principal component analysis (PCA) based on a correlation matrix among samples was used to determine the environmental gradient defined by the physicochemical parameters. The environmental variables were logarithmically transformed (except $\mathrm{pH}$ ) to approximate normality. Prior to the analysis, the units of abundance and biomass data were converted to individuals $\cdot \mathrm{m}^{-2}$ (ind $\cdot \mathrm{m}^{-2}$ ) and $\mathrm{g} \cdot \mathrm{wet} \cdot \mathrm{wt} \cdot \mathrm{m}^{-2}\left(\mathrm{~g} \cdot \mathrm{m}^{-2}\right.$ ), respectively. Simple descriptors of community structure were determined, including the species richness; the Shannon-Wiener, Simpson and Margalef indices; and the relative and absolute abundance of the four most common taxonomic groups (Oligochaeta, Bivalvia, Gastropoda and Chironomidae). The 15 sites in our study differed greatly in the grain size of the substrate as a result of differences in water velocity and water depth and can be roughly classified into three types (mud, sand, and muddy sand) according to the proportion of large particles retained on a 250- $\mu \mathrm{m}$ sieve (Table I and Figure S2, online material). To examine the variation in community structure among the substrate types and seasons, the differences of these descriptors were assessed by Kruskal-Wallis tests followed by Bonferroni-corrected Mann-Whitney pairwise comparisons.

\section{RESULTS}

\section{> ENVIRONMENTAL CHARACTERIZATION}

The results of the overall physical and chemical variables measured at the 15 study sites are showed in Table I. The annual mean water depth varied greatly among the sites from $2.6 \mathrm{~m}$ to $14.7 \mathrm{~m}$. In general, the water was deeper in the northern part of the lake than in other areas. The transparency was quite low with the mean Secchi depth and turbidity of $0.35 \mathrm{~m}$ and 100.92 NTU, respectively. The concentrations of suspended solids were quite high with a mean value of $68.67 \mathrm{mg} \cdot \mathrm{L}^{-1}$. The transparency was higher at two inlet sites (S6: Xiushui, S7: Ganjiang) than in other parts of the lake The nutrient concentrations were relatively high with mean total nitrogen of $1.62 \mathrm{mg} \cdot \mathrm{L}^{-1}$ and mean total phosphorus of $0.115 \mathrm{mg} \cdot \mathrm{L}^{-1}$. Whereas, the concentration of Chl-a was relatively low (ranging from 3.28 to $14.65 \mu \mathrm{g} \cdot \mathrm{L}^{-1}$, with a mean value of $6.51 \mu \mathrm{g} \cdot \mathrm{L}^{-1}$ ). According to the fixed boundary classification system for lake trophic status accepted by the Organization for Economic Co-operation and Development (OECD) (1982), the trophic status of most sites was mesotrophic based on mean Chl-a values except for site S8 which was eutrophic (site S8 was at the outlet of Lake Banghu, which is a smaller lake in the Lake Poyang Nature Reserve characterized by calm conditions). Based on the results from PCA analysis, the first two components accounted for $36.7 \%$ and $29.4 \%$ of the total variance of the environmental variables, respectively (Figure 2). PC1 showed a strong positive relationship with $\mathrm{SD}$ and $\mathrm{Chl}-\mathrm{a}$, while a negative relationship with water depth, turbidity, $\mathrm{SS}$, $\mathrm{TN}$ and $\mathrm{NO}_{3}-\mathrm{N}$. PC2 was most strongly related to $\mathrm{pH}$, conductivity, $\mathrm{DO}, \mathrm{NH}_{4}-\mathrm{N}, \mathrm{TP}$ and $\mathrm{PO}_{4}-\mathrm{P}$. The results of the PCA identified three groups of sites. The sites in northern part of the lake (S11-S15) were characterized by deep water and high values of turbidity, $\mathrm{COD}_{\mathrm{Mn}}, \mathrm{NO}_{3}-\mathrm{N}$ and conductivity. The sites in the southeastern part of the lake (S1-S4) showed high values of DO and phosphorus concentrations. Sites S6 to S9 were characterized by high values of Chl-a and $\mathrm{pH}$.

\section{>ASSEMBLAGE COMPOSITION AND SPATIOTEMPORAL VARIATION}

In total, 42 macrozoobenthic taxa were identified including 3 Oligochaeta, 10 Chironomidae, 13 Bivalvia, 7 Gastropoda and 9 other miscellaneous species (Table II). Corbicula fluminea (89.33 ind $\left.\cdot \mathrm{m}^{-2}\right)$, Limnoperna fortunei (34.33 ind $\left.\cdot \mathrm{m}^{-2}\right)$, Gammaridae sp. (31.00 ind $\cdot \mathrm{m}^{-2}$ ), 


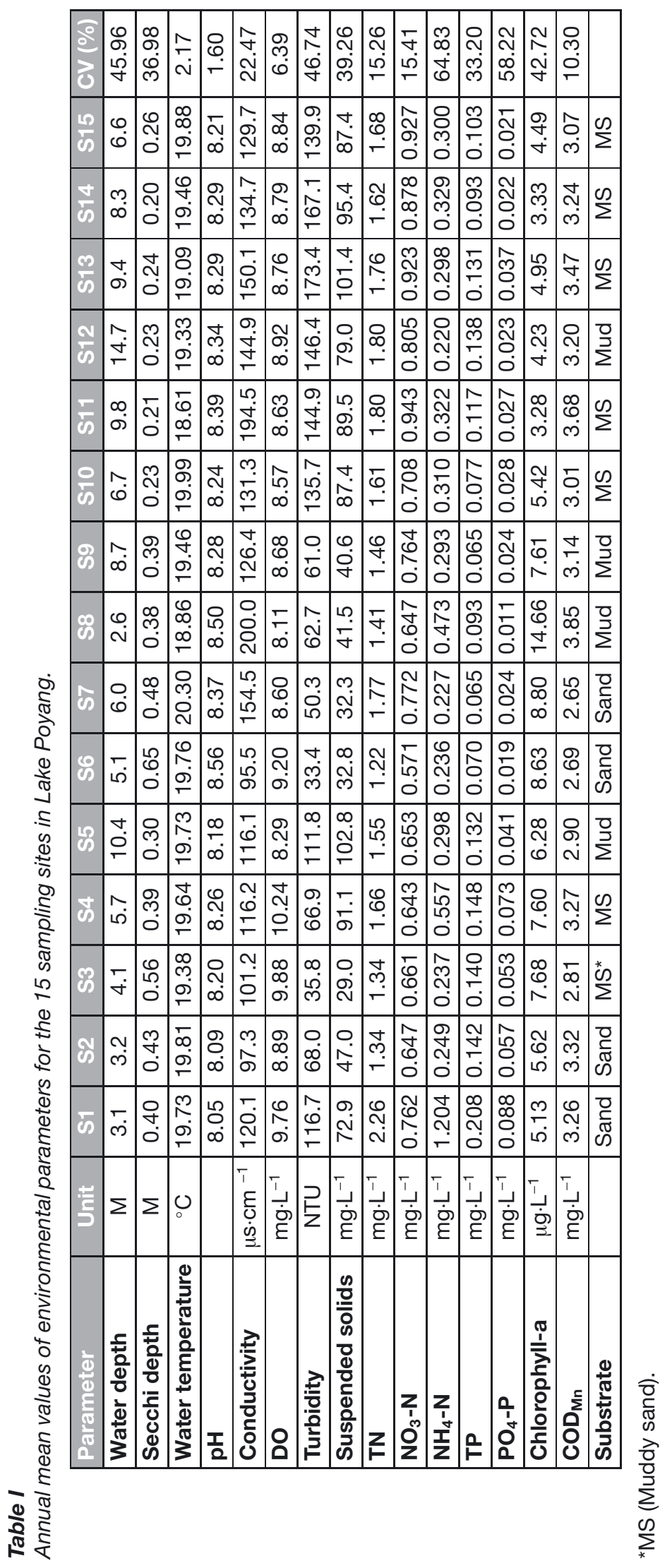




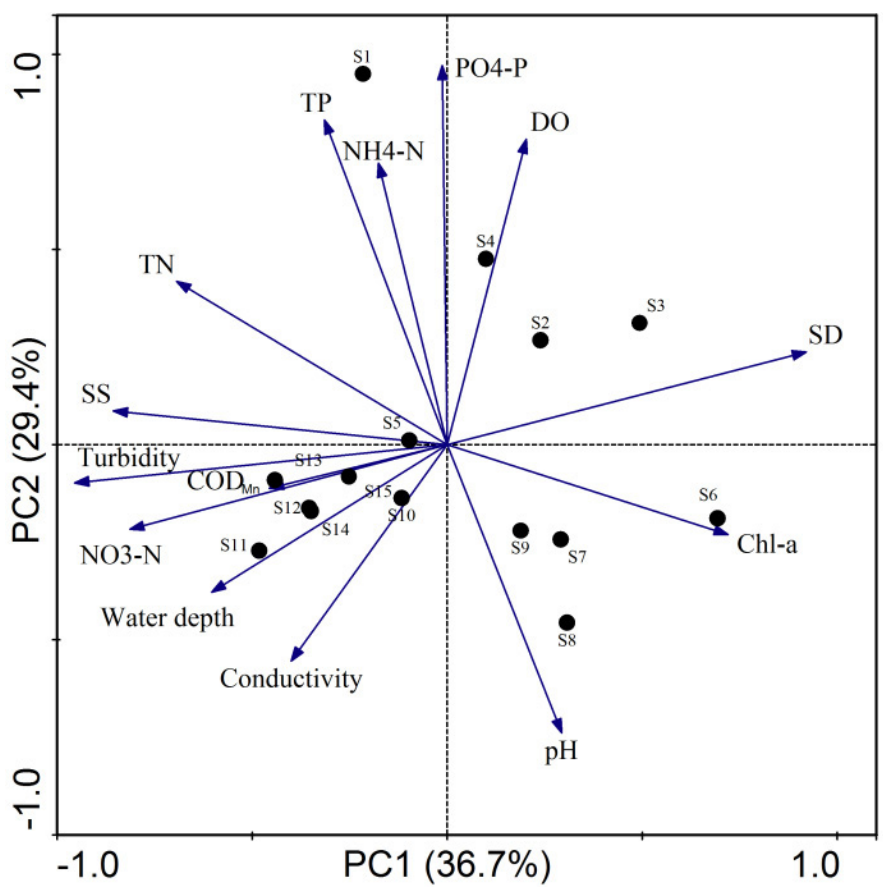

Figure 2

PCA plots of the first 2 principal components of the 14 environmental factors (except water temperature: see Table I). The values on the axes indicate the percentage of total variation explained by each axis.

Nephtys polybranchia (18.17 ind $\left.\cdot \mathrm{m}^{-2}\right)$, Polypedilum scalaenum (10.17 ind $\cdot \mathrm{m}^{-2}$ ) and Branchiura sowerbyi $\left(7.83\right.$ ind $\mathrm{m}^{-2}$ ) dominated the community in terms of abundance and represented $37.69 \%, 14.49 \%, 13.08 \%, 7.66 \%, 4.29 \%$ and $3.31 \%$, respectively, of the total macrozoobenthos abundance. The bivalves C. fluminea, Lamprotula rochechouarti, Arconaia lanceolata and Lamprotula caveata dominated the community in terms of biomass as a result of their large body size, accounting for $46.23 \%, 16.54 \%, 12.25 \%$ and $11.13 \%$ of the total macrozoobenthos biomass, respectively. In our study, six species (C. fluminea, N. polybranchia, B. sowerbyi, L. fortunei, Bellamya aeruginosa and Gammaridae sp.) occurred commonly in Lake Poyang (occurrence $>10$ sites) while 25 species showed extremely low occurrences ( $\leqslant 3$ sites) (Table II).

The mean abundance of total macrozoobenthos varied greatly between $48 \mathrm{ind} \cdot \mathrm{m}^{-2}$ and 920 ind $\cdot \mathrm{m}^{-2}$ (Figure 3A). The lowest mean abundance was recorded at two inlet sites (S6 and S7) with respective values of 75 ind. $\mathrm{m}^{-2}$ and $48 \mathrm{ind} \cdot \mathrm{m}^{-2}$. In general, most sites were dominated by bivalves Gammaridae sp. and N. polybranchia in terms of abundance, except for S8 that was dominated by chironomids (53.40\%). Bivalves (mainly C. fluminea) represented $24.27 \%$ to $86.75 \%$ of the total abundance and were highly abundant in the northern part of the lake. Gammaridae sp. and N. polybranchia constituted $0-31.58 \%$ and $0-36.41 \%$ of the total abundance, respectively. The mean biomass also varied considerably $\left(28-428 \mathrm{~g} \cdot \mathrm{m}^{-2}\right.$, Figure 3B), and the highest biomass values were recorded at $\mathrm{S} 1\left(294 \mathrm{~g} \cdot \mathrm{m}^{-2}\right)$ and S4 $\left(428 \mathrm{~g} \cdot \mathrm{m}^{-2}\right)$, whereas the lowest values were found at S5 $\left(44 \mathrm{~g} \cdot \mathrm{m}^{-2}\right), \mathrm{S} 8\left(28 \mathrm{~g} \cdot \mathrm{m}^{-2}\right)$ and S9 $\left(34 \mathrm{~g} \cdot \mathrm{m}^{-2}\right)$. Bivalves were the most important group representing $46.41 \%$ to $99.53 \%$ of the total biomass. No significant variation in community descriptors (abundance, biomass and diversity indices) was detected among seasons ( $p>0.16$, Figures 4 and 5$)$.

\section{> EFFECTS OF SUBSTRATE TYPE}

Kruskal-Wallis tests indicated that the "substrate" factor strongly affected the descriptors of community structure. The total abundance and biomass of the macrozoobenthos differed significantly among the substrates (Figure 6). In general, the muddy sand substrate 
Table II

Mean and maximum abundance (ind $\left.\cdot \mathrm{m}^{-2}\right)$ and biomass $\left(\mathrm{g} \cdot \mathrm{m}^{-2}\right)$ for the 42 species collected in Lake Poyang. Occurrence (Occ.) is the number of sites at which each species was collected during the four sampling occasions.

\begin{tabular}{|c|c|c|c|c|c|c|c|}
\hline \multirow{2}{*}{ Taxa } & \multicolumn{3}{|c|}{ Abundance } & \multicolumn{3}{|c|}{ Biomass } & \multirow{2}{*}{$\frac{\mathrm{Occ} .}{\%}$} \\
\hline & Mean & Max. & $\%$ & Mean & Max. & $\%$ & \\
\hline \multicolumn{8}{|l|}{ Oligochaeta } \\
\hline Branchiura sowerbyi & 7.83 & 30 & 3.31 & 0.182 & 1.460 & 0.08 & 12 \\
\hline Limnodrilus hoffmeisteri & 6.33 & 40 & 2.67 & 0.012 & 0.112 & 0.01 & 7 \\
\hline Rhyacodrilus sinicus & 4.50 & 20 & 1.90 & 0.004 & 0.008 & $<0.01$ & 3 \\
\hline \multicolumn{8}{|l|}{ Chironomidae } \\
\hline Chironomus semireductus & 2.17 & 20 & 0.91 & 0.008 & 0.062 & $<0.01$ & 3 \\
\hline Clinotanypus sugiyamai & 0.02 & 0.25 & 0.01 & $<0.001$ & $<0.001$ & $<0.01$ & 1 \\
\hline Cryptochironomus defectus & 1.67 & 25 & 0.70 & 0.003 & 0.047 & $<0.01$ & 1 \\
\hline Dicrotendipes lobifer & 1.83 & 20 & 0.77 & 0.001 & 0.009 & $<0.01$ & 2 \\
\hline Dicrotendipes pelochloris & 0.33 & 5 & 0.14 & 0.001 & 0.015 & $<0.01$ & 1 \\
\hline Glyptotendipes sp. & 1.33 & 10 & 0.56 & 0.001 & 0.008 & $<0.01$ & 4 \\
\hline Harnischia fuscimana & 0.17 & 2.5 & 0.07 & $<0.001$ & 0.005 & $<0.01$ & 1 \\
\hline Lipiniella moderata & 2.00 & 25 & 0.84 & 0.013 & 0.147 & 0.01 & 2 \\
\hline Polypedilum scalaenum & 10.17 & 110 & 4.29 & 0.004 & 0.043 & $<0.01$ & 5 \\
\hline Procladius choreus & 0.17 & 2.5 & 0.07 & $<0.001$ & 0.001 & $<0.01$ & 1 \\
\hline \multicolumn{8}{|l|}{ Gastropoda } \\
\hline Alocinma longicornis & 1.33 & 15 & 0.56 & 0.320 & 4.075 & 0.15 & 2 \\
\hline Bellamya aeruginosa & 5.33 & 22.5 & 2.25 & 7.086 & 45.430 & 3.21 & 10 \\
\hline Parafossarulus eximius & 5.00 & 22.5 & 2.11 & 2.447 & 9.977 & 1.11 & 6 \\
\hline Parafossarulus striatulus & 0.33 & 2.5 & 0.14 & 0.118 & 1.450 & 0.05 & 2 \\
\hline Rivularia auriculata & 1.17 & 7.5 & 0.49 & 3.135 & 22.738 & 1.42 & 5 \\
\hline Rivularia bicarinata & 0.33 & 5 & 0.14 & 0.688 & 8.230 & 0.31 & 2 \\
\hline Semisulcospira cancellata & 3.00 & 15 & 1.27 & 0.737 & 3.453 & 0.33 & 8 \\
\hline \multicolumn{8}{|l|}{ Bivalvia } \\
\hline Acuticosta chinensis & 0.33 & 5 & 0.14 & 0.140 & 2.500 & 0.06 & 2 \\
\hline Anodonta woodiana elliptica & 0.67 & 7.5 & 0.28 & 6.392 & 51.150 & 2.90 & 2 \\
\hline Anodonta woodiana pacifica & 0.83 & 10 & 0.35 & 1.936 & 22.303 & 0.88 & 2 \\
\hline Anodonta woodiana woodiana & 0.33 & 5 & 0.14 & 0.907 & 13.601 & 0.41 & 1 \\
\hline Arconaia lanceolata & 1.50 & 10 & 0.64 & 29.56 & 186.45 & 12.25 & 4 \\
\hline Corbicula fluminea & 89.33 & 225 & 37.69 & 102.02 & 371.66 & 46.23 & 15 \\
\hline Cuneopsis pisciculus & 0.17 & 2.5 & 0.07 & 0.015 & 0.218 & 0.01 & 1 \\
\hline Lamprotula caveata & 1.00 & 5 & 0.43 & 26.86 & 168.20 & 11.13 & 4 \\
\hline Lamprotula leai & 0.17 & 2.5 & 0.07 & 17.983 & 269.75 & 8.15 & 1 \\
\hline Lamprotula rochechouarti & 0.67 & 7.5 & 0.28 & 36.503 & 509.98 & 16.54 & 2 \\
\hline Limnoperna fortunei & 34.33 & 285 & 14.49 & 2.859 & 33.624 & 1.30 & 11 \\
\hline Solenaia oleivora & 0.33 & 2.5 & 0.14 & 0.46 & 5.75 & 0.19 & 2 \\
\hline Unio douglasiae & 0.33 & 2.5 & 0.14 & 3.72 & 37.57 & 1.54 & 2 \\
\hline \multicolumn{8}{|l|}{ Miscellaneous others } \\
\hline Neureclipsis sp. & 0.33 & 2.5 & 0.14 & 0.002 & 0.018 & $<0.01$ & 2 \\
\hline Hydropsychidae sp. & 0.17 & 2.5 & 0.07 & 0.002 & 0.033 & $<0.01$ & 1 \\
\hline Ephemera sp. & 0.67 & 5 & 0.28 & 0.046 & 0.369 & 0.02 & 3 \\
\hline Gammaridae sp. & 31.00 & 335 & 13.08 & 0.047 & 0.318 & 0.02 & 10 \\
\hline Nephtys polybranchia & 18.17 & 37.5 & 7.66 & 0.090 & 0.355 & 0.04 & 13 \\
\hline Glossiphonia complanata & 1.17 & 10 & 0.49 & 0.024 & 0.188 & 0.01 & 4 \\
\hline Glossiphonia lata & 1.33 & 20 & 0.56 & 0.018 & 0.269 & 0.01 & 1 \\
\hline Helobdella sp. & 0.17 & 2.5 & 0.07 & 0.037 & 0.558 & 0.02 & 1 \\
\hline Erpobdella sp. & 0.33 & 5 & 0.14 & 0.025 & 0.372 & 0.01 & 1 \\
\hline
\end{tabular}



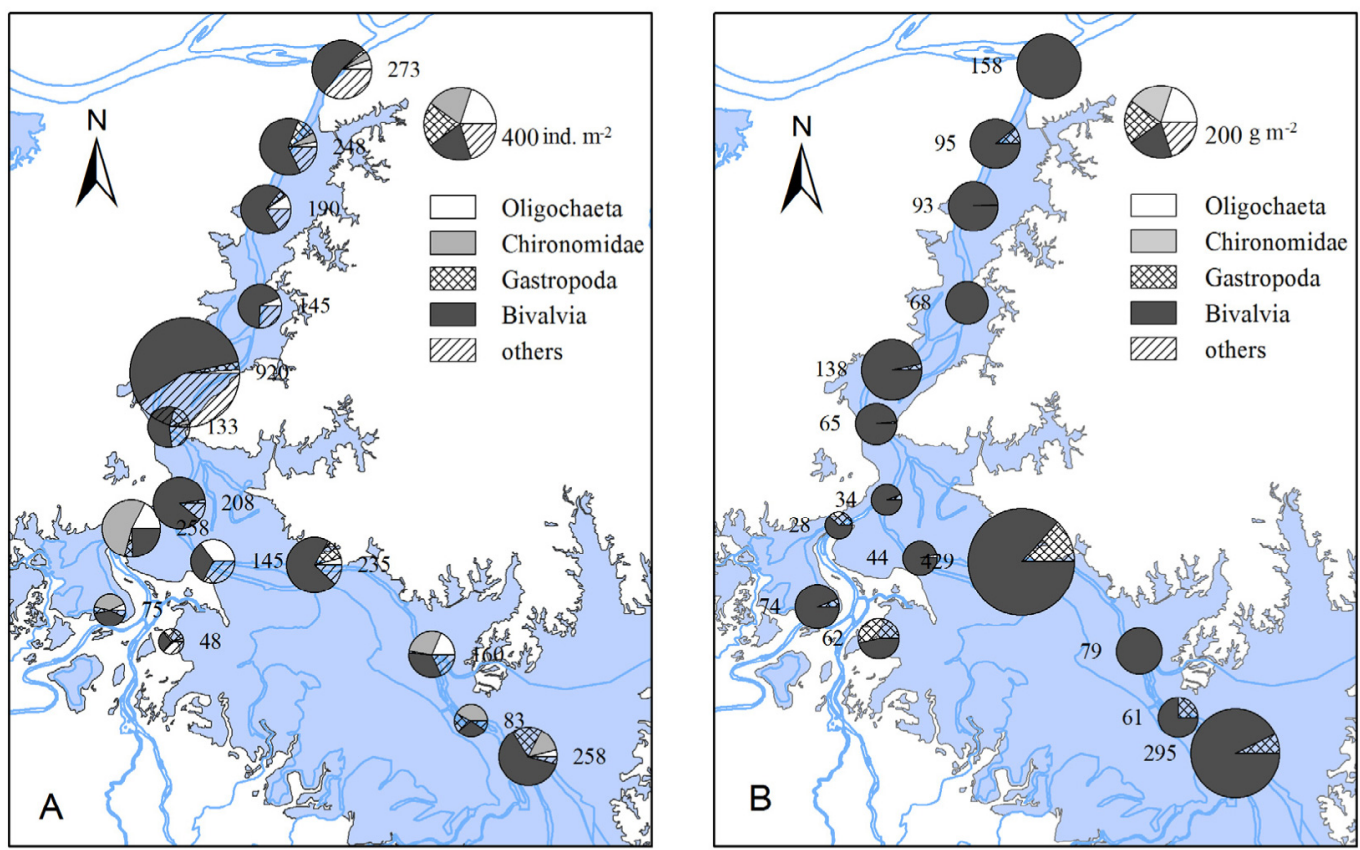

Figure 3

Spatial patterns of mean abundance $(A)$ and biomass $(B)$ for the total macrozoobenthos at the 15 sampling sites in Lake Poyang in 2012.
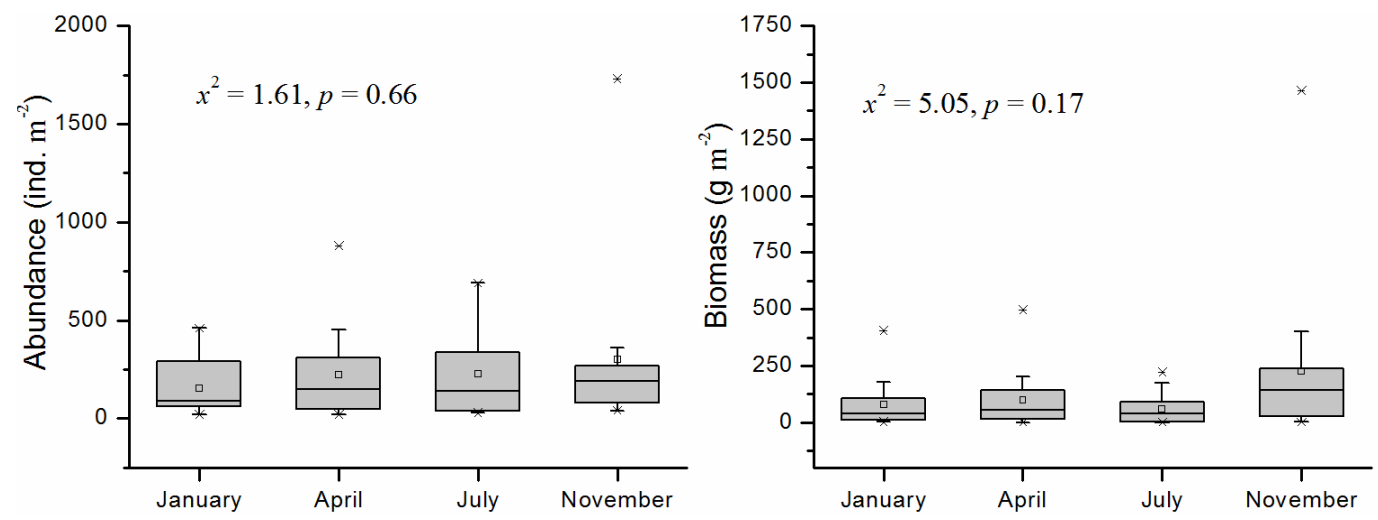

Figure 4

Seasonal variation of the mean abundance and biomass for the total macrozoobenthos in Lake Poyang in 2012.

showed the highest abundance and biomass, while the sand substrate was characterized by the lowest abundance and the mud substrate showed the lowest biomass. The absolute abundance of bivalves increased from sand to muddy sand substrates, whereas oligochaetes and chironomids showed the highest relative and absolute abundance in mud substrates. In terms of the diversity of macrozoobenthic assemblages, the species richness and Margalef indices showed significant or marginally significant differences among substrates $(p=0.049)$. However, the Simpson and Shannon-Wiener diversity indices did not reflect significant or marginally significant differences among substrates (Figure 7). The species richness was highest in the muddy sand substrate, followed by the mud substrate, and it was lowest in the sand substrate.

\section{> DECADAL CHANGES IN MACROZOOBENTHIC ASSEMBLAGES}

A comparison between the present results and historical studies revealed remarkable changes in the abundance of the macrozoobenthos and the identity of the dominant species. 

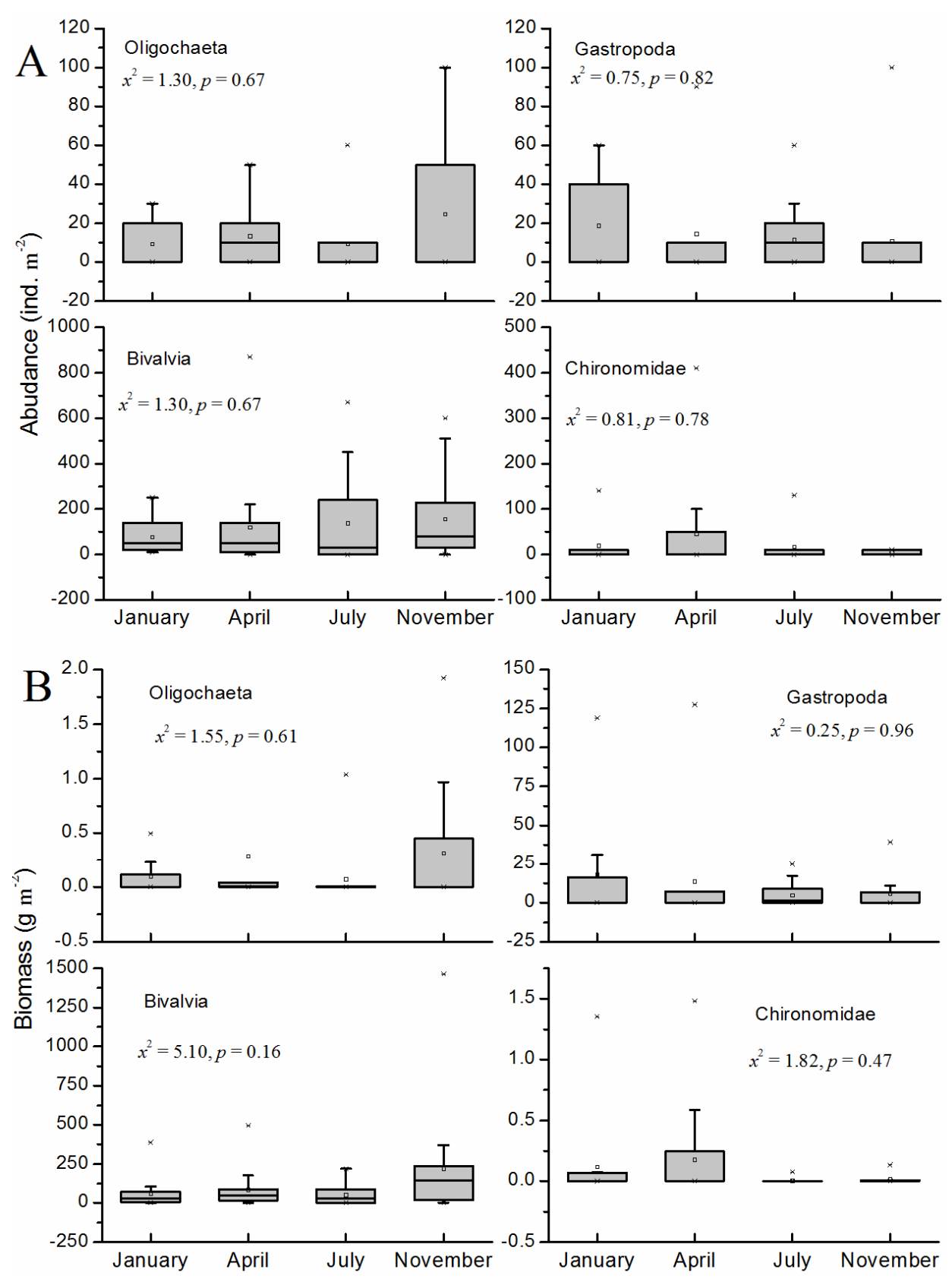

Figure 5

Seasonal variation of the mean abundance $(A)$ and biomass (B) of four taxonomic groups in Lake Poyang in 2012.

The mean total abundance of macrozoobenthos decreased from 724 ind $\cdot \mathrm{m}^{-2}$ in 1992 to 228 ind $\cdot \mathrm{m}^{-2}$ in 2012 (Figure 8), with molluscs representing the greatest proportion of the decline (from $578 \mathrm{ind} \cdot \mathrm{m}^{-2}$ to $149 \mathrm{ind} \cdot \mathrm{m}^{-2}$ ). Aquatic insects also showed a decreasing trend as a result of the declining abundance of non-chironomid insects. In contrast, the abundance of Annelida showed only a small change. The greatest changes in dominant species composition occurred between 1992 and the period of 1998-2012. In 1992, the macrozoobenthic assemblages were dominated by $C$. fluminea, $L$. fortunei, several gastropods, and many large unionids (Table III). After 1998, however, the benthic fauna were dominated by C. fluminea, gastropods, and N. oligobranchia. In addition, a species of Tubificidae (B. sowerbyi) joined the dominant species list in 2008 and 2012. 

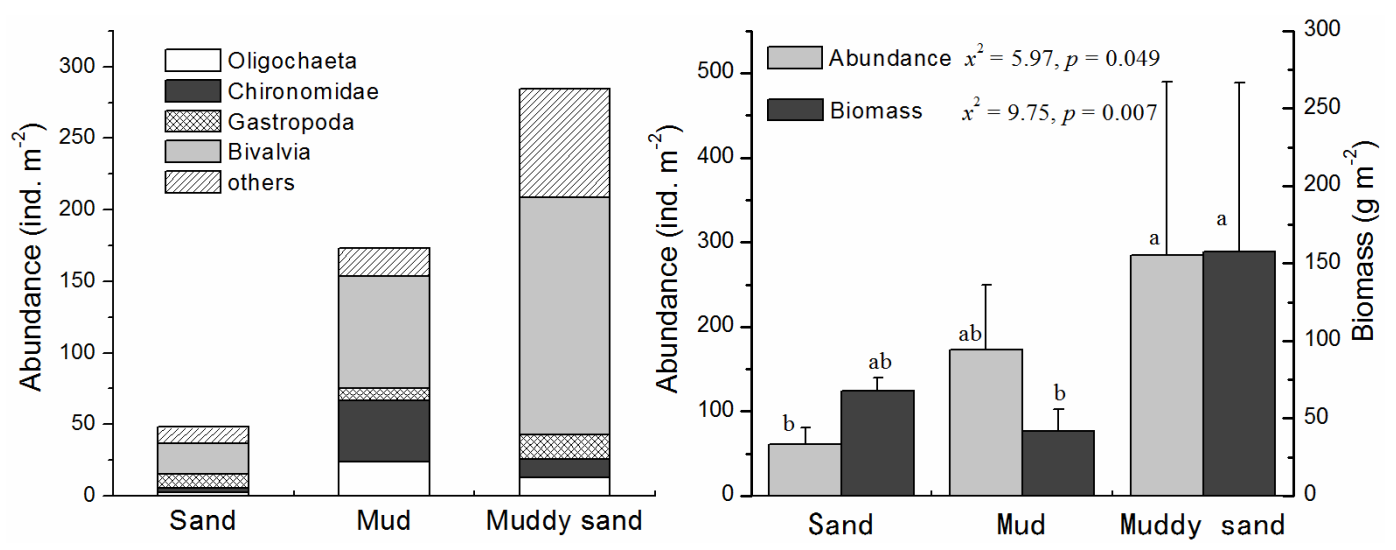

Figure 6

Total abundance and biomass of macrozoobenthos for the three substrate types in Lake Poyang in 2012; means with different letters are significantly different according to multiple comparisons (Bonferronicorrected Mann-Whitney test).
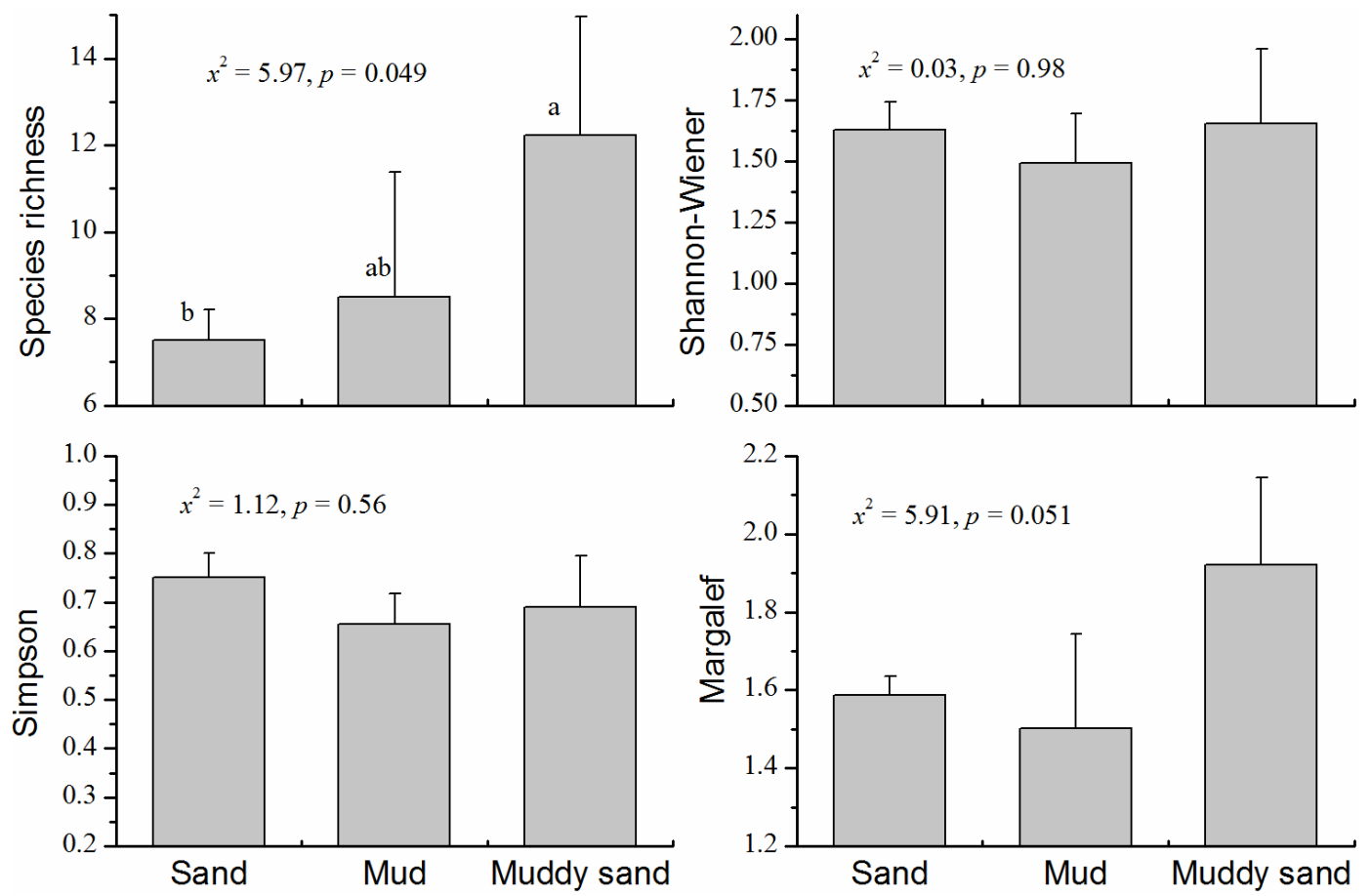

\section{Figure 7}

Comparison of species richness, Shannon-Wiener, Simpson, and Margalef diversity indices among the different substrate types in Lake Poyang in 2012.

\section{DISCUSSION}

\section{> CHARACTERISTICS OF MACROZOOBENTHIC ASSEMBLAGES}

In our study, more than 40 taxa were identified based on the quantitative samples. The species richness of the macrozoobenthos may be underestimated because the study area was restricted to the main river courses and a large proportion of the extensive body of shallow water was left uninvestigated. The macrozoobenthos of Lake Poyang is highly diverse and unique. Combining the present results with other studies, more than 150 taxa have been collected from Lake Poyang. In comparison with the other four of the five largest freshwater lakes (Table IV), Lake Poyang showed the highest richness of macrozoobenthos, with 

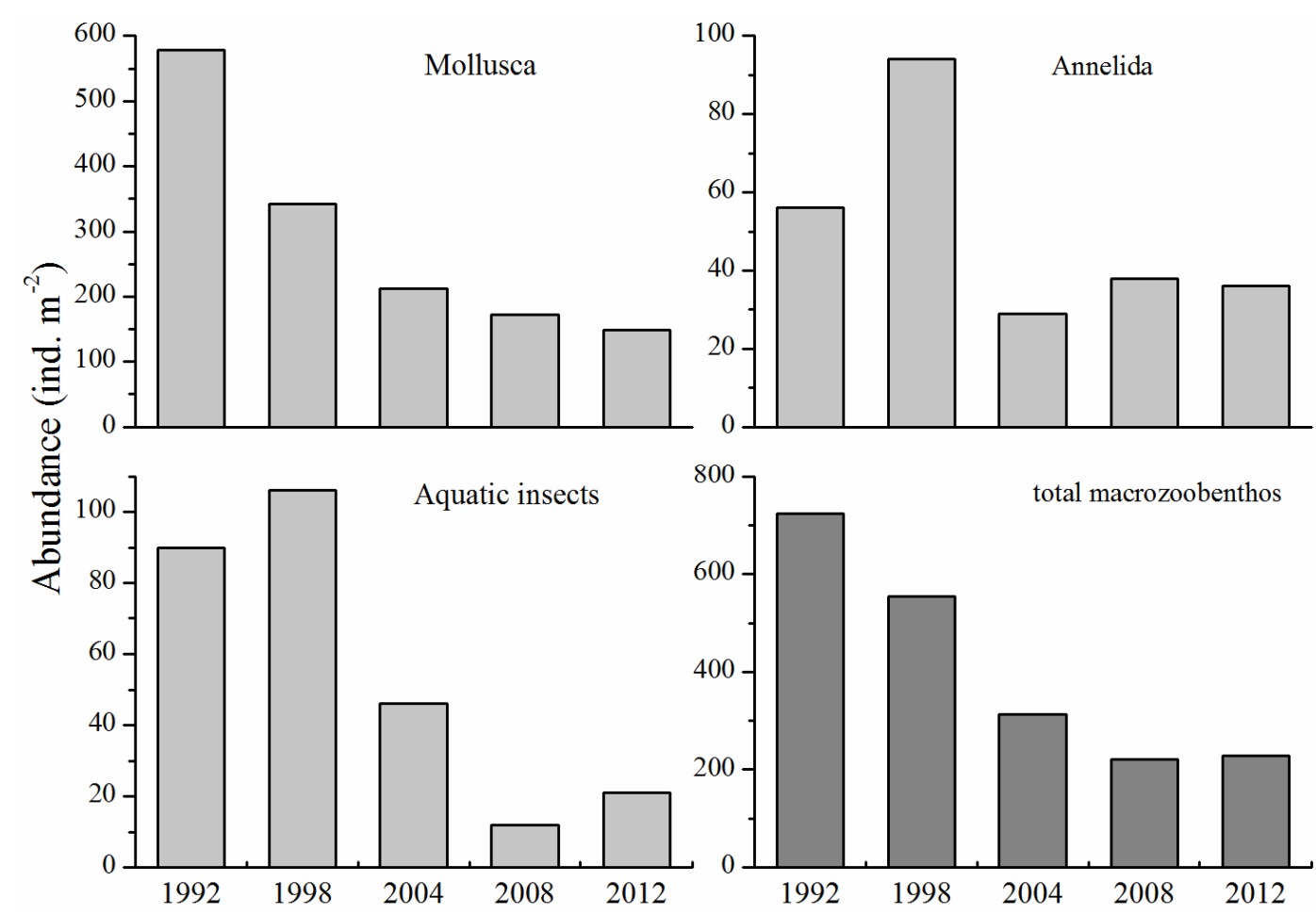

\section{Figure 8}

Long-term changes in the abundance of Mollusca, Annelida, aquatic insects, and total macrozoobenthos from 1992 to 2012 in Lake Poyang.

\section{Table III}

Long-term changes in the dominant species composition of macrozoobenthic assemblages in Lake Poyang.

\begin{tabular}{|c|c|c|c|}
\hline Year & Dominant species & Equipment & Sources \\
\hline 1992 & $\begin{array}{c}\text { Corbicula fluminea, Limnoperna fortune, large Unionoida } \\
\text { (Lamprotula leai, L.caveata, L. tientsinensis, Unio douglasiae, } \\
\text { Lancelaria sp., Cuneopsis pisciculus, Arconaia lancelata, } \\
\text { Anodonta woodiana woodiana, Hyriopsis cumingii, Cristaria } \\
\text { plicata), Gastropod (Bellamya spp., Semisulcospira cancelata, } \\
\text { Radix sp.), chironomids }\end{array}$ & $\begin{array}{c}\text { Peterson grab } \\
\left(0.079 \mathrm{~m}^{2}\right), \\
\text { Ekman }\left(0.021 \mathrm{~m}^{2}\right)\end{array}$ & $\begin{array}{c}\text { Xie et al. } \\
(1995)\end{array}$ \\
\hline $\mathbf{1 9 9 8}$ & $\begin{array}{c}\text { C. fluminea, Gastropod (Bellamya spp., Parafossarulus } \\
\text { striatulus, Alocinma longicornis), Gammaridae sp., } \\
\text { N. polybranchia, }\end{array}$ & $\begin{array}{c}\text { Peterson grab } \\
\left(0.0625 \mathrm{~m}^{2}\right)\end{array}$ & $\begin{array}{c}\text { Wang et al. } \\
(1999)\end{array}$ \\
\hline $\mathbf{2 0 0 8}$ & $\begin{array}{c}\text { C. fluminea, Gastropod (Bellamya sp., P. eximius, } \\
\text { A. longicornis, S. cancelata), N. polybranchia, B. sowerbyi }\end{array}$ & $\begin{array}{c}\text { Peterson grab } \\
\left(0.0625 \mathrm{~m}^{2}\right)\end{array}$ & $\begin{array}{c}\text { Ou Yang et al. } \\
(2009)\end{array}$ \\
\hline $\mathbf{2 0 1 2}$ & $\begin{array}{c}\text { C. fluminea, L. fortune, Bellamya sp., Gammaridae sp., } \\
\text { N. polybranchia, B. sowerbyi, Polypedilum scalaenum }\end{array}$ & $\begin{array}{c}\text { Peterson grab } \\
\left(0.05 \mathrm{~m}^{2}\right)\end{array}$ & this study \\
\hline
\end{tabular}

mollusc richness several times higher than that of the other lakes. Based on the study of Zhang et al. (2013), 46 species of gastropods and 62 species of bivalves have been recorded in Lake Poyang representing $21 \%$ and $72 \%$ of the total gastropods and bivalves respectively, in the Yangtze Basin; 21 of the gastropod species and 46 of the bivalve species are endemic to China and a large proportion only occur in large Yangtze-connected lakes (Lake Poyang and Lake Dongting). Even in the other four largest lakes, only 6-43 species of molluscs were recorded in different sampling periods (Table IV). In our study, two endemic gastropods were collected (Rivularia auriculata, R. bicarinata). N. polybranchia, an estuarine and marine species, was the dominant species in the lake. However, Lake Poyang is located 
Y.J. Cai et al.: Knowl. Managt. Aquatic Ecosyst. (2014) 414, 09

\section{Table IV}

Species richness of macrozoobenthos in the other four of the five largest freshwater lakes in China.

\begin{tabular}{|l|c|c|c|c|c|c|}
\hline $\begin{array}{l}\text { Lake } \\
\text { Area }\left(\mathrm{km}^{2}\right)\end{array}$ & Period & Annelida & Mollusca & Arthropod & Total & Sources \\
\hline Dongting & $1981-1982$ & 14 & 26 & 39 & 80 & Lu (1985) \\
$\mathbf{2 4 3 2}$ & 1995 & 10 & 20 & 28 & 59 & Dai et al. (2000) \\
& 2001 & 18 & 15 & 14 & 51 & Xie et al. (2007) \\
\hline Taihu & 1988 & 8 & 23 & 27 & 59 & Huang (2001) \\
$\mathbf{2 4 2 5}$ & $2008-2009$ & 13 & 12 & 17 & 42 & Cai et al. (2012a) \\
\hline Hongze & $1987-1990$ & 7 & 43 & 25 & 76 & Zhu and Dou (1993) \\
$\mathbf{1 5 9 7}$ & $2010-2011$ & 5 & 6 & 6 & 14 & Zhang et al. (2012) \\
\hline Chaohu & $1980-1981$ & 8 & 33 & 14 & 55 & Hu and Yao (1981) \\
$\mathbf{7 6 9}$ & $2002-2003$ & 12 & 16 & 13 & 42 & Unpublished data \\
\hline
\end{tabular}

approximately $500 \mathrm{~km}$ from the East China Sea and might have had a reasonable historical connection with marine fauna. Lake Poyang was found to be the upper distributional limit of N. polybranchia for shallow lakes along the Yangtze River (Cai et al., 2013).

The high diversity of macrozoobenthos in Lake Poyang appears attributable to habitat heterogeneity within this large and seasonally flooded lake. According to the theory of spatial heterogeneity (Tews et al., 2004), more heterogeneous and complex habitats support a more complex and diverse fauna (Erman and Erman, 1984). Large spatial heterogeneity provides a variety of substrata for living, feeding, reproduction, and protection against predation by other invertebrates, fishes, and birds. Lake Poyang is characterized by a broad flat landscape dominated by gradual slopes, as is typical of floodplains (Finlayson et al., 2010). The habitat characteristics vary greatly among regions, primarily as a result of hydrological complexity. For example, the variation in terms of substrate types from silt to sand at our sampling sites was caused by differences in the water velocity and water depth (Gong et al., 2006). The abundant aquatic macrophytes in wetlands also provide diverse habitats for macrozoobenthos (Finlayson et al., 2010).

In this study, the benthic fauna were dominated by bivalves (mainly C. fluminea). As shown in Figure 2, the abundance and biomass of bivalves in Lake Poyang were $13-510 \mathrm{ind} \cdot \mathrm{m}^{-2}$ and $17-372 \mathrm{~g} \cdot \mathrm{m}^{-2}$, respectively. Similar features have been found in Lake Dongting, another large Yangtze-connected lake and the 2nd largest freshwater lake in China (Dai et al., 2000; Xie et al., 2003). The great abundance of bivalves in Lake Poyang might be a result of the prevalence of sandy bottoms, which are preferred by the dominant filterer C. fluminea (Karatayev et al., 2003). In contrast, many of the disconnected lakes along the Yangtze River are characterized by muddy bottoms and high trophic status (approximately $85.9 \%$ of the lakes were eutrophic) (Yang et al., 2010), and the benthic fauna are mainly dominated by pollution-tolerant taxa (oligochaetes and chironomids). For example, Lake Chaohu and Meiliang Bay of Lake Taihu (the 5th and 3rd largest freshwater lakes in China, respectively) are exclusively dominated by oligochaetes and chironomids as a result of long-term eutrophication and cyanobacterial blooms (Cai et al., 2012b).

\section{> FACTORS REGULATING THE MACROZOOBENTHIC ASSEMBLAGES}

In our study, we found that the standing crops and diversity of the macrozoobenthos differed significantly among substrate types. It has been reported that the sediment type (sand vs. mud) is one of the dominant factors responsible for the spatial distribution of macrozoobenthos in terms of feeding types (Chutter, 1969). Suspension feeders (e.g., bivalves) are more abundant on a sand flat where the water velocity prevents the deposition of organic matter on the bottom and the current activity brings more potential food than weaker currents would supply. In contrast, large numbers of deposit-feeders (e.g., oligochaetes and chironomids) are more abundant on a mud flat, where the weak currents allow organic matter to settle and provide an adequate source of nutrition (Newell et al., 1958). Several studies have indicated that the filtering structures of suspension feeders can become clogged in mud flat 
environments (Donohue and Irvine, 2003; Madon et al., 1998). In our study, one species of bivalve (i.e. C. fluminea) was a suspension feeder and showed the highest abundance on muddy sand bottoms. In contrast, the species of oligochaetes and chironomids were deposit feeders and were more abundant on mud bottoms. Note that sandy bottoms presented the lowest standing crops and diversity, whereas the highest values were observed on muddy sand bottoms. In Lake Poyang, sandy bottom sites are characterized by high water velocities (e.g. $>0.3 \mathrm{~m} \cdot \mathrm{s}^{-1}$ at sites 6 and 7 ), which may prevent the settlement of many species. In contrast, muddy sand bottoms may be suitable habitats for both suspension feeders and deposit feeders. Similar to our findings, former studies have shown that muddy sand substrates are favorable for the survival of $C$. fluminea and $N$. oligobranchia in other large shallow lakes in the Yangtze River Basin, e.g., Lakes Taihu (Cai et al., 2012a) and Hongze (Zhang et al., 2012). We did not find an obvious relationship between water quality and macrozoobenthic assemblages in a preliminary redundancy analysis (RDA), with no environmental variables were selected by forward selection (Monte Carlo estimation of 4999 permutations, $p<0.05$ ). These results may be attributable to the short residence time (21 days) and high water velocity $\left(0.3-2.85 \mathrm{~m} \cdot \mathrm{s}^{-1}\right.$ in main channel) in Lake Poyang. Hence, the measured environmental variables only represent a snapshot of water quality and cannot reflect long-term integrated effects. In contrast, the variation in sediment characteristics was relatively smaller than the variation in water chemistry. Other studies also found that benthic assemblages showed weak relationship with water chemistry in lotic ecosystems (Buss et al., 2002; Wang et al., 2012). For instance, Pan et al. (2011) found that water velocity is the most important factor structuring macrozoobenthic assemblages in Lakes Poyang, Dongting and Shijiu.

\section{> DECADAL CHANGES AND IMPLICATIONS FOR CONSERVATION}

Our results showed that macrozoobenthic assemblages changed greatly in abundance and in the identity of the dominant species over long time periods in Lake Poyang. The total abundance of bivalves decreased, and large unionids were excluded from the list of dominant species. Extensive sand extraction may have had severely negative impacts on the benthic fauna of Lake Poyang. Based on the study by de Leeuw et al. (2010), the volume of sand extraction was 236 million. $\mathrm{m}^{3}$.year ${ }^{-1}$ in 2005-2006, which represented approximately $40 \%$ of the regional demand for sand in the lower Yangtze Valley. The dredging-induced changes in high turbidity, substrate instability, and sediment grain size might have affected the survival, recruitment, and growth of unionids. Several studies have revealed that increased turbidity can reduce the foraging activity and growth of mussels (Osterling et al., 2007; Bucci et al., 2008; Österling et al., 2010), in which processes several potential mechanisms may be involved. The fraction of fine sediments, which were more abundant at sand extraction sites, was generally responsible for clogging sediments and resulted in low oxygen and high ammonia conditions (Augspurger et al., 2007). The silt content may also have been positively correlated with nutrient levels in the surface sediment, which can be associated with increased oxygen consumption and can have toxic effects on unionids, reducing the survival of both juvenile and adult mussels (Cope et al., 2008). Furthermore, fine sediment and suspended particles can significantly reduce the survival of unionids by restricting their feeding behaviors (Donohue and Irvine, 2003). In contrast, species of Annelida prefer living in mud and fine sand sediments and selectively feed on finer organic particles (Anlauf and Moffitt, 2008). Substrate stability is important for mussel habitats, and a positive relationship between substrate stability and mussel abundance has been observed in several studies (Allen and Vaughn, 2010; Johnson and Brown, 2000). However, intensive sand extraction severely disturbs the bottom sediment and directly removes large unionids but not oligochaetes, chironomids, or small bivalves.

In conclusion, the combination of our results with historical studies shows that the macrozoobenthos assemblages in Lake Poyang are diverse and unique. The abundance and dominant species composition in the main channel have changed significantly over the long term. These changes may be ascribed to sand mining. The ecological impacts of these changes 
remain speculative; however, they are not inconceivable. It is suggested that the negative impacts of dredging on the biodiversity hotspots of Lake Poyang merit further attention. Additional research on the biodiversity and relevant regulating factors of Lake Poyang is required to gain scientific knowledge in order to support the high ecological quality and sustainable use of this unique lake ecosystem. Moreover, a large area of the shallow water body (seasonal flooded wetland) remains uninvestigated, and further studies of the benthic fauna and other aquatic biota should focus on the remaining area.

\section{ACKNOWLEDGEMENTS}

We are grateful to the Lake Poyang Laboratory for Wetland Ecosystem Research (PLWER) for providing regular monitoring data. We would also like to thank the many PLWER staff and postgraduates who assisted in the processing of macrozoobenthos samples. We especially thank Dr. Sanyuan Jiang for his linguistic improvements and useful comments. This work was supported by the National Basic Research Program of China (Grants 2012CB417000, 2012CB956100) and the National Natural Sciences Foundation of China (Grant 31300396). Finally, we thank the anonymous reviewers for their constructive comments and helpful suggestions.

\section{REFERENCES}

Allen D.C. and Vaughn C.C., 2010. Complex hydraulic and substrate variables limit freshwater mussel species richness and abundance. J.N. Am. Benthol. Soc., 29, 383-394.

Anlauf K.J. and Moffitt C.M., 2008. Models of stream habitat characteristics associated with tubificid populations in an intermountain watershed. Hydrobiologia, 603, 147-158.

APHA, 2012. Standard Methods for the Examination of Water and Wastewater 22 ed. American Public Health Association, Washington, DC.

Arthington A.H., Naiman R.J., McClain M.E. and Nilsson C., 2010. Preserving the biodiversity and ecological services of rivers: new challenges and research opportunities. Freshwater Biol., 55, 1-16.

Augspurger T., Dwyer F.J., Ingersoll C.G. and Kane C.M., 2007. Advances and opportunities in assessing contaminant sensitivity of freshwater mussel (Unionidae) early life stages. Environ. Toxicol. Chem., 26, 2025-2028.

Bucci J.P., Showers W.J., Levine J.F. and Usry B., 2008. Valve gape response to turbidity in two freshwater bivalves (Corbicula fluminea and Lampsilis radiata). J. Freshwater Ecol., 23, 479-483.

Buss D.F., Baptista D.F., Silveira M.P., Nessimian J.L. and Dorvillé L.F.M., 2002. Influence of water chemistry and environmental degradation on macroinvertebrate assemblages in a river basin in southeast Brazil. Hydrobiologia 481, 125-136.

Cai Y.J., Gong Z.J. and Qin B.Q., 2012a. Benthic macroinvertebrate community structure in Lake Taihu, China: Effects of trophic status, wind-induced disturbance and habitat complexity. J. Great Lakes Res., 38, 39-48.

Cai Y.J., Jiang J.H., Zhang L., Chen Y.W. and Gong Z.J., 2012b. Simplification of macrozoobenthic assemblages related to anthropogenic eutrophication and cyanobacterial blooms in two large shallow subtropical lakes in China. Aquat. Ecosyst. Health Manage., 15, 81-91.

Cai Y.J., Jiang J.H., Zhang L., Chen Y.W. and Gong Z.J., 2013. Structure of macrozoobenthos in lakes along the Yangtze River and relationships with environmental characteristics. Acta Ecologica Sinica, 33, 4985-4999 (in chinese with english abstract).

Chutter F.M., 1969. The effects of silt and sand on the invertebrate fauna of streams and rivers. Hydrobiologia, 34, 57-76.

Cope W.G., Bringolf R.B., Buchwalter D.B., Newton T.J., Ingersoll C.G., Wang N., Augspurger T., Dwyer F.J., Barnhart M.C. and Neves R.J., 2008. Differential Exposure, Duration, and Sensitivity of Unionoidean Bivalve Life Stages to Environmental Contaminants. J.N. Am. Benthol. Soc., 27, 451-462. 
Covich, A., Austen, M., Baerlocher, F., Chauvet, E., Cardinale, B., Biles, C., Inchausti P., Dangles O., Solan M. and Gessner M., 2004. The Role of Biodiversity in the Functioning of Freshwater and Marine Benthic Ecosystems. Bioscience, 54, 767-775.

Dai Y.Z., Tang S.Y. and Zhang J.B., 2000. The distribution of zoobenthos species and bioassessment of water quality in Dongting Lake. Acta Ecologica Sinica, 20, 277-282 (in chinese with english abstract).

Dalu T., Clegg B. and Nhiwatiwa T., 2012. Macroinvertebrate communities associated with littoral zone habitats and the influence of environmental factors in Malilangwe Reservoir, Zimbabwe. Knowl. Manag. Aquat. Ecosyst., 406, 1-5.

Davidson T.A., Mackay A.W., Wolski P., Mazebedi R., Murray-Hudson M. and Todd M., 2012. Seasonal and spatial hydrological variability drives aquatic biodiversity in a flood-pulsed, sub-tropical wetland. Freshwater Biol., 57, 1253-1265.

de Leeuw, J., Shankman D., Wu G., de Boer W.F., Burnham J., He Q., Yesou H. and Xiao J., 2010. Strategic assessment of the magnitude and impacts of sand mining in Poyang Lake, China. Reg. Environ. Change, 10, 95-102.

Donohue I. and Irvine K., 2003. Effects of sediment particle size composition on survivorship of benthic invertebrates from Lake Tanganyika, Africa. Archiv. Hydrobiol., 157, 131-144.

Erman D. and Erman N., 1984. The response of stream macroinvertebrates to substrate size and heterogeneity. Hydrobiologia, 108, 75-82.

Feng L., Hu C.M., Chen X.L., Cai X.B., Tian L.Q. and Gan W.X., 2012. Assessment of inundation changes of Poyang Lake using MODIS observations between 2000 and 2010. Remote Sens. Environ., 121, 80-92.

Finlayson M., Harris J., McCartney M., Young L. and Zhang C., 2010. Report on Ramsar visit to Poyang Lake Ramsar site, P.R. China, 12-17 April 2010. Secretariat of the Ramsar Convention, BeiJing, $34 \mathrm{p}$.

Gong X.F., Chen C.L., Zhou W.B., Jian M.F. and Zhang Z.H., 2006. Assessment on heavy metal pollution in the sediment of Poyang Lake. Environmental Science, 27, 732-736 (in chinese with english abstract).

Hu J.Y. and Yao W.Q., 1981. Investigation of macrozoobenthos in Lake Chaohu, China. Journal of Anhui University (Natural Science Edition), 2, 159-173 (in chinese).

Huang Y.P. (ed.), 2001. The Water Environment and Pollution Control of Lake Taihu. Science Press, Beijing, Beijing, 271 p. (in chinese).

Jiang J.H., Dou H.S. and Su S.D., 2009. Freshwater lake groups in the middle and lower reaches of the Yangtze and Huaihe Rivers. ChangJiang Press, Wuhan 428 p. (in chinese).

Johnson P.D. and Brown K.M., 2000. The importance of microhabitat factors and habitat stability to the threatened Louisiana pearl shell, Margaritifera hembeli (Conrad). Can. J. Zool., 78, 271-277.

Johnson R.K., Goedkoop W. and Sandin L., 2004. Spatial scale and ecological relationships between the macroinvertebrate communities of stony habitats of streams and lakes. Freshwater Biol., 49, 1179-1194.

Karatayev A.Y., Burlakova L.E., Kesterson T. and Padilla D.K., 2003. Dominance of the Asiatic clam, Corbicula fluminea (Muller), in the benthic community of a reservoir. J. Shellfish Res., 22, 487-493.

Liu Y.Y., Zhang W.Z., Wang Y.X. and Wang E.Y., 1979. Economic Fauna of China: Freshwater Mollusca. Science Press, Beijing, 134 p. (in chinese).

Liu Y.J., Ou Yang S. and Wu X.P., 2008. Distribution and status of freshwater bivalves in the Poyang Lake. JiangXi Science, 26, 280-299 (in chinese with english abstract).

Lu Q.G., 1985. Bioassessment of water quality using macrozoobenthos in Lake Dongting. Environmental Science, 6, 59-63 (in chinese).

Madon S., Schneider D., Stoeckel J. and Sparks R., 1998. Effects of inorganic sediment and food concentrations on energetic processes of the zebra mussel, Dreissena polymorpha: implications for growth in turbid rivers. Can J. Fish Aquat. Sci., 55, 401-413.

Morse J.C., Yang L.F. and Tian L.X., 1994. Aquatic Insects of China Useful for Monitoring Water Quality. Hohai University Press, Nanjing, 570 p.

Negishi J.N., Sagawa S., Kayaba Y., Sanada S., Kume M. and Miyashita T., 2012. Mussel responses to flood pulse frequency: the importance of local habitat. Freshwater Biol., 57, 1500-1511. 
Newell R., Seiderer L. and Robinson J., 2001. Animal: sediment relationships in coastal deposits of the eastern English Channel. J. Mar. Biol. Assoc. U.K., 81, 1-9.

Nilsson C., Reidy C.A., Dynesius M. and Revenga C., 2005. Fragmentation and flow regulation of the world's large river systems. Science, 308, 405-408.

OECD (Organization for Economic Cooperation and Development), 1982. Eutrophication of waters, monitoring assessment and control, Paris.

Osterling, E.M., Bergman, E., Greenberg, L.A., Baldwin, B.S. and Mills E.L., 2007. Turbidity-mediated interactions between invasive filter-feeding mussels and native bioturbating mayflies. Freshwater Biol., 52, 1602-1610.

Österling M.E., Arvidsson B.L. and Greenberg L.A., 2010. Habitat degradation and the decline of the threatened mussel Margaritifera margaritifera: influence of turbidity and sedimentation on the mussel and its host. J. Appl. Ecol., 47, 759-768.

Ou Yang S., Zhan C., Chen T.H., Wu H.L. and Wu X.P., 2009. Species diversity and resource assessment of macrozoobenthos in Poyang Lake. Journal of Nanchang University (Engineering \& Technology), 31, 9-13 (in chinese with english abstract).

Pan B.Z., Wang H.J., Liang X.M. and Wang H.Z., 2011. Macrozoobenthos in Yangtze floodplain lakes: patterns of density, biomass, and production in relation to river connectivity. J.N. Am. Benthol. Soc. , 30, 589-602.

Tang H.Q., 2006. Biosystematic study on the chironomid larvae in China (Diptera: Chironomidae). Nankai University, TianJing, 945 p. (in chinese with english abstract).

Tews J., Brose U., Grimm V., Tielbörger K., Wichmann M.C., Schwager M. and Jeltsch F., 2004. Animal species diversity driven by habitat heterogeneity/diversity: the importance of keystone structures. J. Biogeogr., 31, 79-92.

Thomaz S., Bini, L. and Bozelli R., 2007. Floods increase similarity among aquatic habitats in riverfloodplain systems. Hydrobiologia, 579, 1-13.

Tockner K. and Stanford J.A., 2002. Riverine flood plains: present state and future trends. Environ. Conserv., 29, 308-330.

Tockner K., Ward J., Edwards P. and Kollmann J., 2002. Riverine landscapes: an introduction. Freshwater Biol. , 47, 497-500.

Tolonen K.T., Hamalainen H., Holopainen I.J. and Karjalainen J., 2001. Influences of habitat type and environmental variables on littoral macroinvertebrate communities in a large lake system. Archiv. Hydrobiol., 152, 39-67.

Vörösmarty C.J., Mclntyre P., Gessner M.O., Dudgeon D., Prusevich A., Green P., Glidden S., Bunn S.E., Sullivan C.A. and Liermann C.R., 2010. Global threats to human water security and river biodiversity. Nature, 467, 555-561.

Wang H.Z., 2002. Studies on Taxonomy, Distribution and Ecology of Microdrile Oligochaetes of China, with Descriptions of Two New Species from the Vicinity of the Great Wall Station of China, Antarctica. Higher Education Press, Beijing, 228 p. (in chinese).

Wang H.Z., Xie Z.C., Wu X.P. and Liang Y.L., 1999. A preliminary study of zoobenthos in the Poyang Lake, the largest freshwater lake of China, and its adjoining reaches of Changjiang River. Acta Hydrobiologica Sinica, 23, 132-138.

Wang H.Z., Xu Q.Q., Cui Y.D. and Liang Y.L., 2007. Macrozoobenthic community of Poyang Lake, the largest freshwater lake of China, in the Yangtze floodplain. Limnology 8, 65-71.

Wang X.Z, Cai Q.H., Jiang W.X. and Qu X.D., 2012. Inter-annual patterns in the stability and persistence of stream macroinvertebrate communities: relationship with water physicochemical parameters. J. Freshwater Ecol. , 28, 79-90.

Ward J., Tockner K., Arscott D. and Claret C., 2002. Riverine landscape diversity. Freshwater Biol., 47, 517-539.

Weatherhead M.A. and James M.R., 2001. Distribution of macroinvertebrates in relation to physical and biological variables in the littoral zone of nine New Zealand lakes. Hydrobiologia, 462, 115-129.

Wu H.L., OuYang S., Zhan C. and Wu X.P., 2008. The Summ er Freshwater Snails Conmmunity Structure in Poyang Lake. JiangXi Science, 26, 97-101 (in chinese with english abstract).

Wu X.P., Ou Yang S. and Hu Q.Y., 1994. Bivalves (Mollusca) of the Poyang Lake. Journal of Nanchang University (Natural Science), 18, 249- 252 (in chinese with english abstract). 
Xie Q.M., Li Y. and Xiong G.G., 1995. Studies on the ecology of zoobenthos and the estimation of bottom-fish productivity in Poyang Lake. JiangXi Science, 13, 161-170 (in chinese with english abstract).

Xie Z.C, Cai Q.H, Tang T., Ma K., Liu R.Q. and Ye L., 2003. Structure of macrozoobenthos of the east Dongting Nature Reserve, with emphasis on relationships with environmental variables. J. Freshwater Ecol., 18, 405-413.

Xie Z.C., Zhang J.Q., Chen J., Ma K., Liu R.Q., Wang Y.P. and Cai Q.H., 2007. Spatial distributional pattern of macrozoobenthos and pollution evaluation in East Lake Dongting Reserve. Journal of Lake Sciences, 19, 289-298 (in chinese with english abstract).

Xiong L.F., Ou Yang S., Chen T.H., Qi T. and Wu X.P., 2011a. Diversity patterns of freshwater mussels in Poyang Lake area. Journal of Nanchang University (Natural Science) 35, 288-295 (in chinese with english abstract).

Xiong L.F., Ou Yang S., Chen T.H., Qi T. and Wu X.P., 2011b. The comparative study of resource status on freshwater mussel in two lakes of different usage in Poyang Lake area. Journal of Shanghai Ocean University, 20, 204-210 (in chinese with english abstract).

Yang G.S., Ma R.H., Zhang L., Jiang J.H., Yao S.C., Zhang M. and Zeng H.A., 2010. Lake status, major problems and protection strategy in China. Journal of Lake Sciences, 22, 799-810 (in chinese with english abstract).

Zhang C.W., Zhang T.L., Zhu T.B., Li W. and Xie Z.C., 2012. Community structure of macrozoobenthos and its relationship with environmental factors in Lake Hongze. Journal of Hydroecology, 33, 27-33 (in chinese with english abstract).

Zhang M.H., Xu L., Xie G.L., Liu Y.B., Liu X.M., Song S.C., Ou Yang S. and Wu X.P., 2013. Species diversity, distribution and conservation of freshwater mollusk in Poyang Lake basin. Marine Sciences 37, 114-124 (in chinese with english abstract).

Zhu S.Q. and Dou H.S., 1993. Lake Hongze. Press of University of Science and Technology of China, Hefei, $227 \mathrm{p}$ (in chinese). 


\section{Online Material}




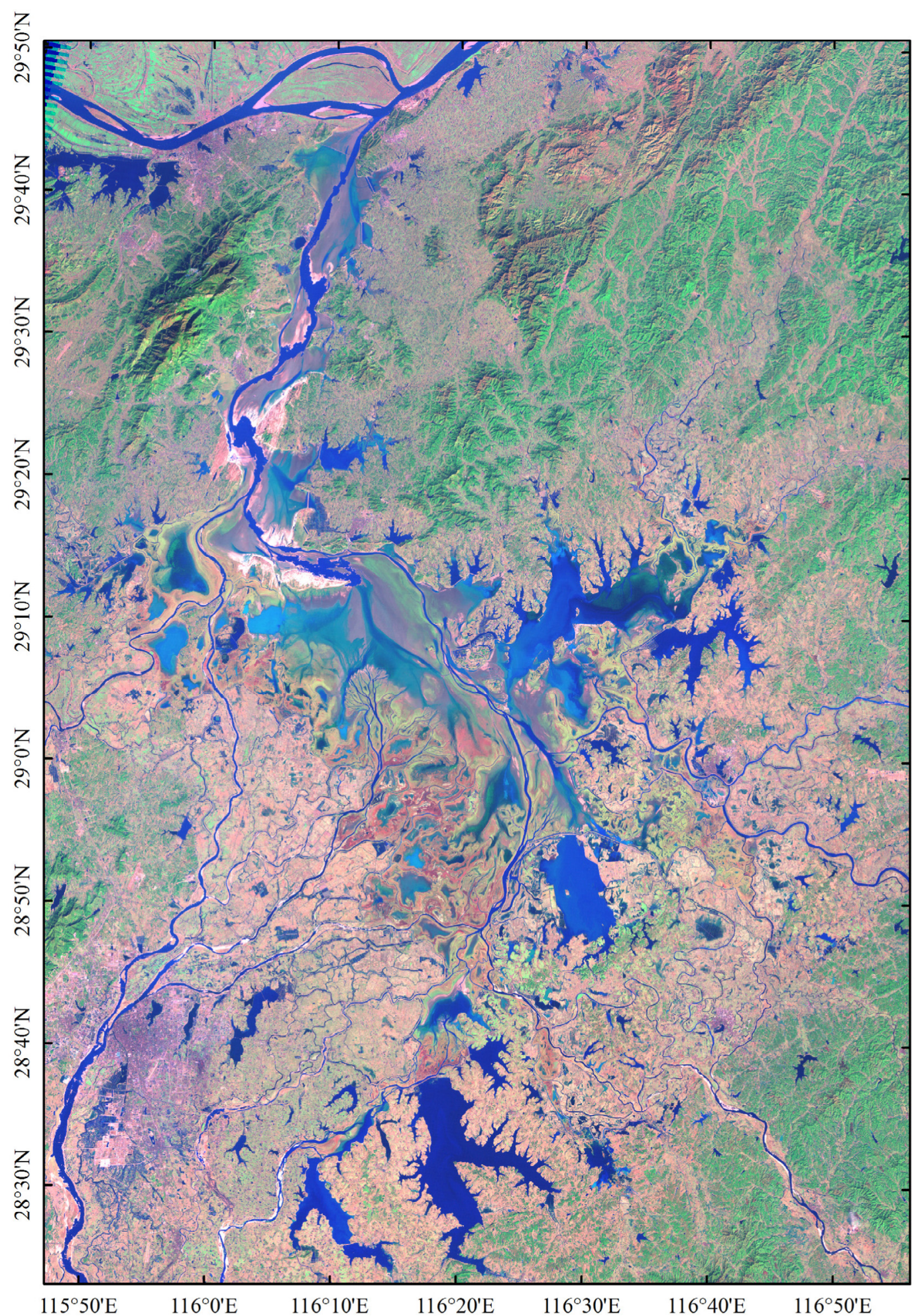

Figure $S 1$

Landsat TM image of Lake Poyang during dry season (January 11th, 2009). 


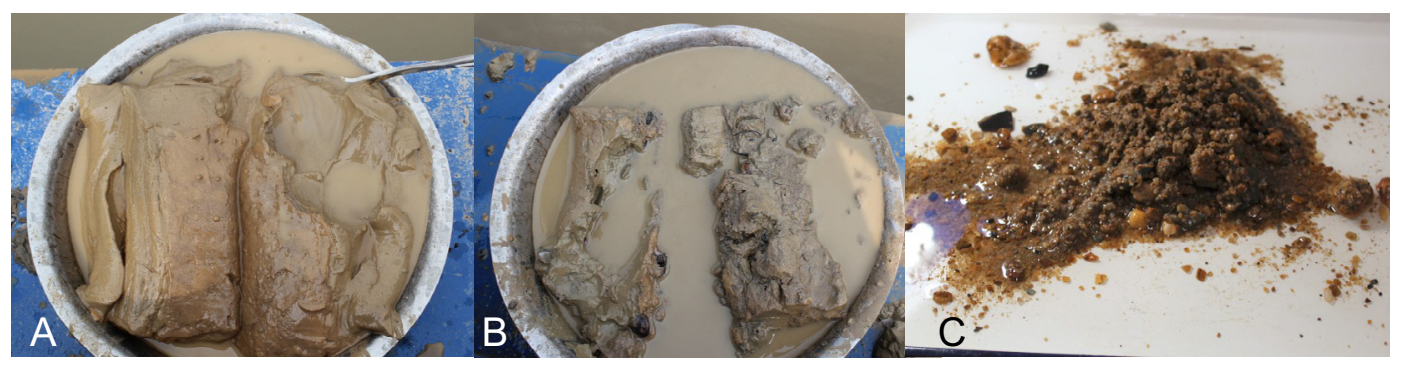

Figure 52

Photographs of three different substrate types in Lake Poyang. A (mud, Site 5); B (muddy sand, Site 4); $C$ (sand, Site 6). These photographs were taken in October 2012. 